\title{
Pigmented Euglenophytes in a natural and shallow lake in the semiarid region of Paraíba State, Brazil
}

\author{
GABRIELLE JOANNE MEDEIROS ARAUJO ${ }^{1}$, JOSÉ ETHAM DE LUCENA BARBOSA ${ }^{1}$ and \\ LUCIANA GOMES BARBOSA ${ }^{2,3}$
}

(received: July 13, 2011; accepted: December 15, 2011)

\begin{abstract}
Pigmented Euglenophytes in a natural and shallow lake in the semiarid region of Paraíba State, Brazil). A floristic survey of the class Euglenophyceae in Panati Lake ( $7^{\circ} 11^{\prime} 14^{\prime \prime} \mathrm{S}$ and $36^{\circ} 49^{\prime} 52^{\prime \prime} \mathrm{W}$ ) is presented. The samples were collected between November 2005 and April 2007 along the margins of the lake, and a total of 29 taxa were collected, described, and illustrated, comprising 11 specifics and 18 infraspecifics, with five typical and 13 non-typical varieties. The genus Trachelomonas showed the greatest richness (13 taxa), followed by the genus Lepocinclis (seven taxa). All of the 29 taxa cataloged had been previously reported for Brazil, most with wide geographical distributions, but all were new records for Paraíba State, and 25 new for northeastern Brazil - reflecting the need for more taxonomic studies of the Euglenophyceae in these locations.
\end{abstract}

Key words - Euglenophyceae, flora, phytoplankton

\section{INTRODUCTION}

The division Euglenophyta is part of a diverse line of free-living flagellated protists comprising species that are phototrophic, phagotrophic, osmotrophic, and bacteriophagic (Brosnan et al. 2003, Marin et al. 2003). The phototrophic species are denominated pigmented Euglenophyta, and the heterotrophs are considered colorless or unpigmented Euglenophyta. The forms with chloroplasts, together with the secondary heterotrophs, constitute the class Euglenophyceae, a lineage that diverged through a single secondary endosymbiotic event with a Chlorophyte (Gibbs 1978).

Heterotrophic behavior can also be seen in the pigmented representatives of this group, which can photosynthesize carbohydrates and/or ingest organic material in the water column by phagocytosis - which helps explain the strong affinity of this group for eutrophic environments. Their ability to move freely in aquatic environments confers advantages in turbid and shallow waters, where they can capture nutrients present in deeper layers and then migrate to the euphotic zone (Giani et al. 1999).

The pigmented euglenophytes are widely distributed globally, especially in continental aquatic ecosystems

\footnotetext{
1. Universidade Estadual da Paraíba, Centro de Ciências Biológicas e da Saúde, Laboratório de Ecologia Aquática (LEAq). Av. das Baraúnas, 351, Campus Universitário Bodocongó, 58101-001 Campina Grande, PB, Brazil

2. Universidade Federal da Paraíba, Centro de Ciências Agrárias, Departamento de Fitotecnia e Ciências Ambientais, Laboratório de Ecologia Vegetal, Campus II, 58397-000 Areia, PB, Brazil

3. Corresponding author: lucianabarbosa@cca.ufpb.br
}

(Alves-da-Silva \& Bridi 2004b), but their taxonomy remains problematic in spite of their very common occurrences (Alves-da-Silva \& Bicudo 2009). Published studies concerning the systematics and ecology of phytoplanktonic communities in northeastern Brazil are still quite rare, especially those concerning the Euglenophyceae, but include the work of Freire-de-Góis (1978) concerning the implications of the presence of species of the genus Trachelomonas in water treatment systems. There have been no publications yet, however, concerning this group in Paraíba State. The principal objective of the present study was to undertake a floristic survey of the class Euglenophyceae in Panati Lake and to increase our taxonomic knowledge of this group in continental aquatic ecosystems in the semiarid region of Brazil.

\section{MATERIAL AND METHODS}

Panati Lake (7॰11'14" S and 3649' $52^{\prime \prime}$ W; $560 \mathrm{~m}$ above sea level) is a temporary shallow lake with a maximum depth of $1.5 \mathrm{~m}$ and an abundance of aquatic macrophytes (Crispim \& Freitas 2005). The lake is located near the Atlantic coast along the western margin of the PB-238 state highway (between Assunção/PB - Taperoá/PB), and is in direct contact with a retaining wall of that roadway (Souza \& Abílio 2006). The lake is part of the sub-basin of the Taperoá River. The soils there are predominantly non-alkaline, brown, shallow, and litholic. The regional climate is sub-desert, hot, tropical, with average temperatures near $25^{\circ} \mathrm{C}$; there is a long dry-season lasting more than eight months, and an average annual rainfall of about $300 \mathrm{~mm}_{\text {year }}{ }^{-1}$.

Ten collections were made between November/2005 and April/2007 along the banks of Panati Lake. Collections were 
made during each sampling period to quantitatively analyze the Euglenophyceae present and to determine nutrient concentrations in the water. Material for the taxonomic analyses were collected with a plankton net (20 $\mu \mathrm{m}$ weave) using horizontal sweeps. After collecting, the samples were transferred to $300 \mathrm{~mL}$ polyethylene flasks and preserved in $4 \%$ formalin neutralized with borax, in quantities equal to the sample volume. Observations and studies of the microorganisms were undertaking using an Olympus CBA binocular microscope equipped with a camera lucida, digital camera, and a reticulated micrometer lens.

Rainfall data (mm) was obtained from Laboratory of Meteorology, Water Resources, and Remote Sensing of Paraíba (LMRS, PB). Water transparency (m) was measured using a Secchi disk. Samples for nutrient analyses were collected in the sub-surface waters of the lake using a Van Dorn-type sampler (3L). Water temperature $\left({ }^{\circ} \mathrm{C}\right)$ and electrical conductivity $\left(\mu \mathrm{S} \mathrm{cm}^{-1}\right)$ were measured in situ using a Horiba model B-213 multi-parameter probe and a Cole-Parmer portable digital conductivity meter respectively. Alkalinity $\left(\mathrm{mgCaCO}_{3} \mathrm{~L}^{-1}\right)$ was determined by titration following Mackereth et al. (1978). Nutrient concentrations were determined by using colorimetric methods: ammonia and nitrites following Mackereth et al. (1978); nitrate following Rodier (1975); and orthophosphate and total phosphorus following Golterman et al. (1978).

Identifications to specific and infra-specific levels were performed based on morphological and metric characteristics of the taxa, based on studies by Yacubson (1974, 1981), Tell \& Conforti (1986), Conforti (1994), Alves-da-Silva \& Hahn (2004), Alves-da-Silva \& Bridi (2004a, b), Salazar (2004), Zaburlín et al. (2004), Rai \& Rai (2007), Alves-da-Silva \& Fortuna (2006, 2008), and Alves-da-Silva \& Tamanaha (2008). The ratios of cell length to width were also calculated $(\mathrm{R} 1 / \mathrm{w})$.

The specimens evaluated were deposited in the algae collection (microalgae) of the Prof. Jaime Coelho de Morais herbarium (EAN), Centro de Ciências Agrárias da Universidade Federal da Paraíba, using their collection numbers (followed by the collection dates): EAN15468 (14/11/2005), EAN15469 (09/01/2006), EAN15470 (20/03/2006), EAN15471 (05/06/2006), EAN15472 (24/07/ 2006), EAN15473 (18/09/2006), EAN15474 (11/12/2006), EAN15475 (15/01/2007), EAN15476 (26/02/07), and EAN15477 (16/04/07).

\section{RESULTS}

Twenty-nine taxa of the genera Cryptoglena, Euglena, Lepocinclis, Phacus, Trachelomonas, and Strombomonas were identified (table 1). Of these, 18 were identified to the infra-specific level, with five typical and 13 non-typical varieties. All of these taxa constituted first reports for Paraíba State, and 25 were first reports for northeastern Brazil. The analyses of environmental variables indicated that the taxa occurred at water temperatures between 26 and $29^{\circ} \mathrm{C}$, maximum transparency of $1 \mathrm{~m}$, with nutrients showing large differences in their concentrations over time (table 1).

\section{EUGLENACEAE}

Cryptoglena Ehrenberg 1831.

Cryptoglena skujae Marin \& Melkonian emend. Kosmala \& Zakryś, J. Phycol. 43: 174, 180, fig. 18. 2007.

Figure 1

Cell elliptical, 12.5-20.0 $\mu \mathrm{m}$ long, 10.0-15.0 $\mu \mathrm{m}$ wide; $\mathrm{R} 1 / \mathrm{w}=1.20-1.33$; anterior pole slightly depressed in the central portion; posterior pole rounded and without caudal process; pellicle apparently smooth; two chloroplasts in the shape of lateral discs; two large paramylon grains in the form of lateral shields.

Material examined: EAN15476 and EAN15477.

Geographical distribution: South America, Asia, and Europe. Has been cited for the central-western, northern, southeastern, and southern regions of Brazil (as Phacus agilis Skuja).

Euglena Ehrenberg 1830.

Euglena caudata Hübner, Progr. Realg. Stralsund, p.13. 1886.

Figures 2 and 30

Cell fusiform, 42.5-62.5 $\mu \mathrm{m}$ long, 12.5-17.5 $\mu \mathrm{m}$ wide; $\mathrm{Rl} / \mathrm{w}=2.9-3.4$; anterior pole rounded; posterior pole extended as a colorless, conical caudal process, ca. $7.5 \mu \mathrm{m}$ long; cytoplasm with numerous smooth or lobed discoid chloroplasts, each with double pyrenoids; numerous small, oval or discoid paramylon grains.

Material examined: EAN15476 and EAN15477.

Geographical distribution: South America, Asia, and Europe. Has been cited for the central-western, northern, and southeastern regions of Brazil.

Euglena ehrenbergii Klebs var. baculifera (Thompson) Gojdics, Madison, The Univ. of Wisc. Press, p.108-109. 1953.

Figures 3 and 31

Cell cylindrical, 157.5-162.5 $\mu \mathrm{m}$ long, 22.5-25.0 $\mu \mathrm{m}$ wide; $\mathrm{Rl} / \mathrm{w}=6.5-7.0$; both poles rounded; cytoplasm with numerous discoid chloroplasts; ovoid nucleus in the lower body.

Material examined: EAN15471 and EAN15476.

Geographical distribution: North and South America. Reported only from Northern Brazil.

Commentary: Differs from the typical variety by the presence of a single and very elongated paramylon grain. 


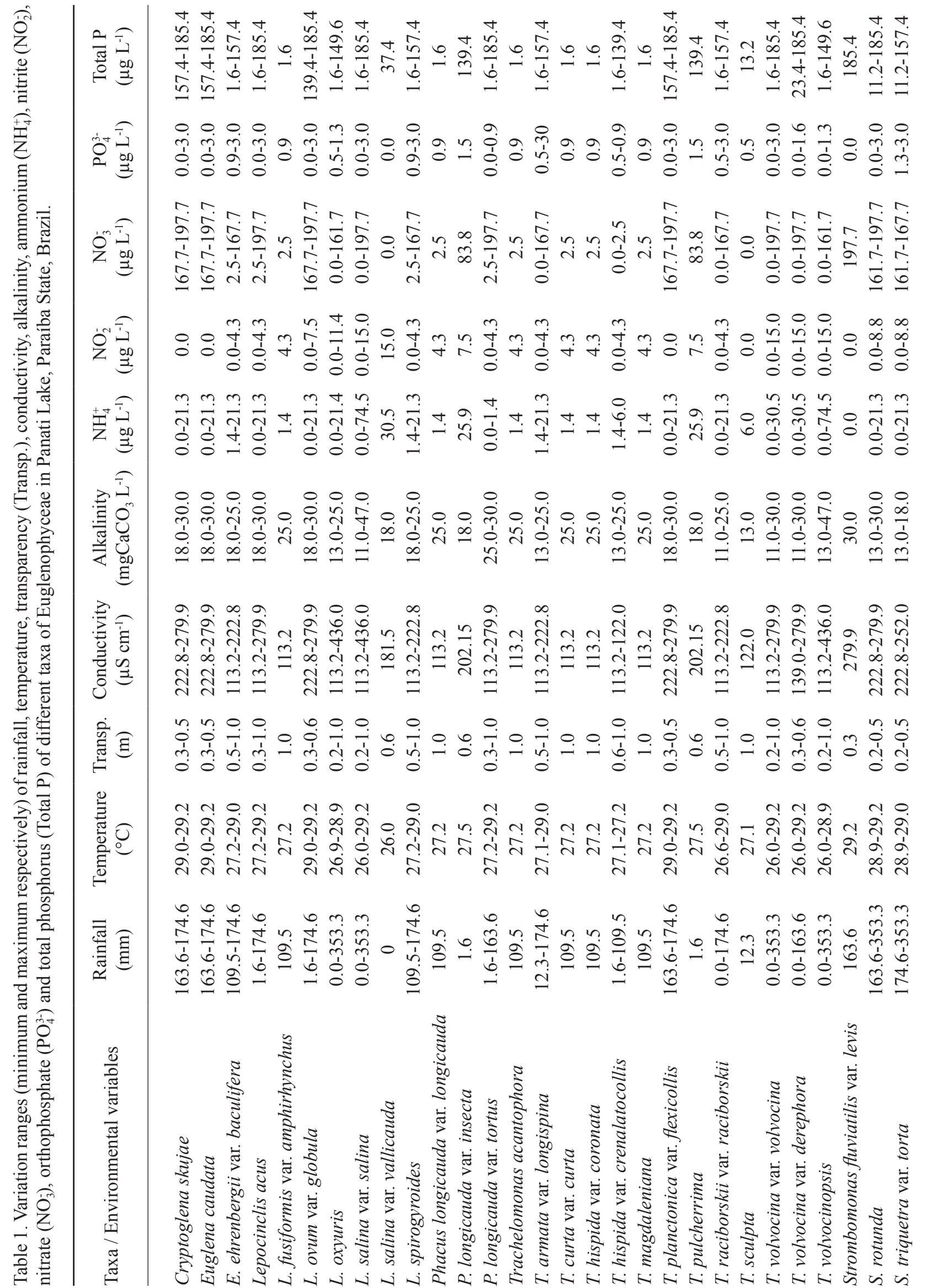


Lepocinclis Perty 1852.

Lepocinclis acus (Müller) Marin \& Melkonian in Marin, Palm, Klingberg \& Melkonian, Protist 154: 104. 2003.

Figures 4 and 32

Cell fusiform, 102.0-185.0 $\mu \mathrm{m}$ long, 5.0-12.5 $\mu \mathrm{m}$ wide; $\mathrm{Rl} / \mathrm{w}=14.0-20.5$; anterior pole thin and truncated; posterior pole thin, terminating in a long caudal process, 20.0-47.5 $\mu \mathrm{m}$ long; numerous discoid chloroplasts; paramylon grains rod-shaped, 12.5-17.5 $\times$ 3.7-5.0 $\mu \mathrm{m}$.

Material examined: EAN15471, EAN15475, EAN15476 and EAN15477.

Geographical distribution: Cosmopolitan. Has been cited for central-western, northern, southeastern, and southern Brazil (as Euglena acus Ehr. var. acus).
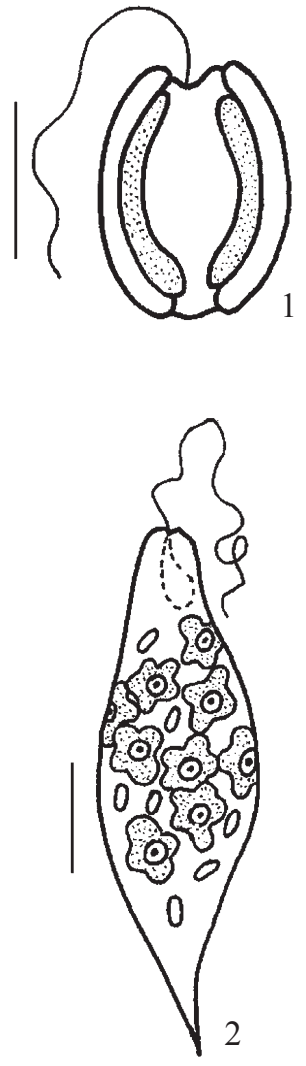

2

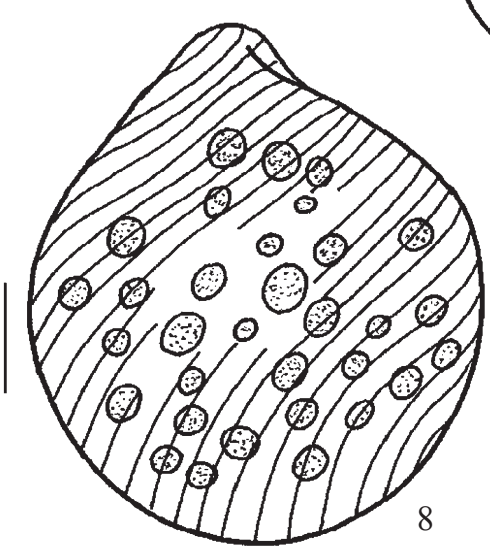

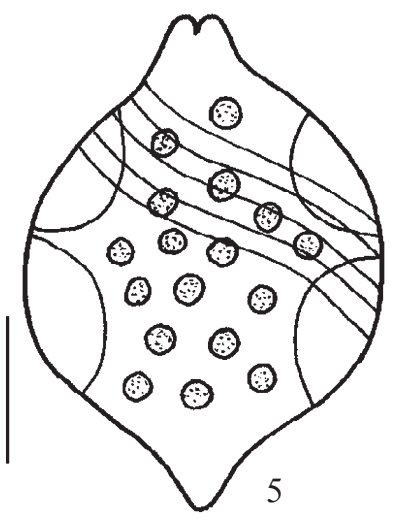
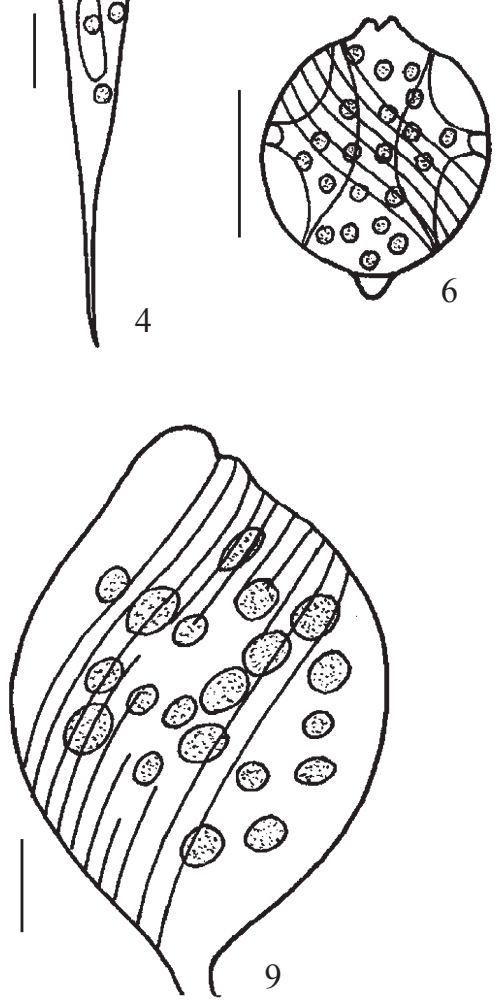

4

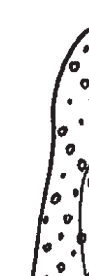

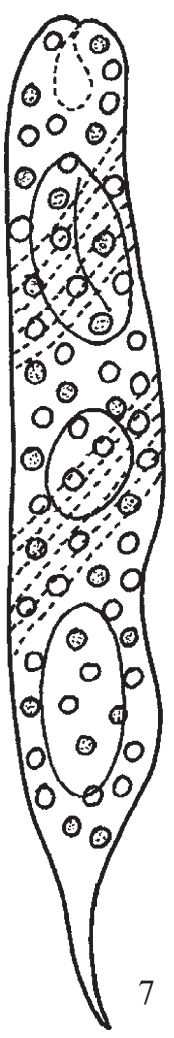
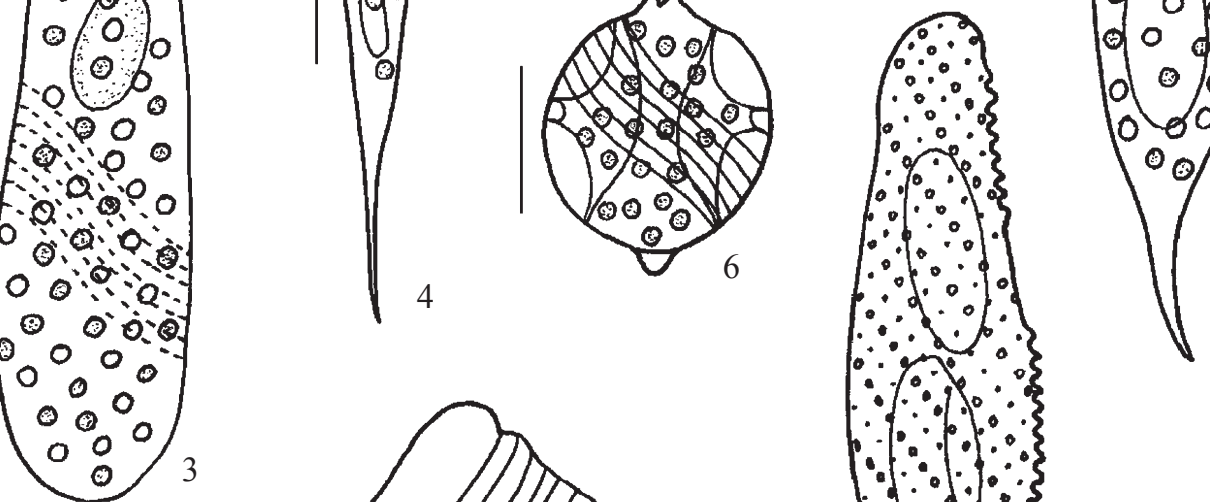

Figures 1-10. 1. Cryptoglena skujae. 2. Euglena caudata. 3. Euglena ehrenbergii var. baculifera. 4. Lepocinclis acus. 5. Lepocinclis fusiformis var. amphirhynchus. 6. Lepocinclis ovum var. globula. 7. Lepocinclis oxyuris. 8. Lepocinclis salina var. salina. 9. Lepocinclis salina var. vallicauda. 10. Lepocinclis spirogyroides. Bar $=10 \mu \mathrm{m}$. 
Lepocinclis fusiformis (Carter) Lemmermann emend. Conrad var. amphirhynchus Nygaard, Dank. Vid. Selsk. Biol. Skr., 7(1): 167, fig. 101. 1949.

Figures 5 and 33

Cell citriform, 30.0-35.0 $\mu \mathrm{m}$ long, 22.5-27.5 $\mu \mathrm{m}$ wide; $\mathrm{R} 1 / \mathrm{w}=1,27-1,40$; anterior pole with obtuse mammilla; posterior pole with short caudal process; pellicle colorless with levorotatory striations; numerous discoid chloroplasts; two thick grains of annular paramylon, lateral and opposite.

Material examined: EAN15471.

Geographical distribution: Africa, South America, Asia, and Europe. Has been cited for northern and southern Brazil.

Commentary: This variety differs from the typical variety by having a more prominent anterior pole.

Lepocinclis ovum (Ehrenberg) Lemmermann var. globula (Perty) Lemmermann, Kryptogamenfl. Bradenburg, 3(4): 505. 1910.

Figures 6 and 34

Cell sub-globose, 17.5-20.0 $\mu \mathrm{m}$ long, $15.0 \mu \mathrm{m}$ wide; $\mathrm{Rl} / \mathrm{w}=1.17-1.33$; anterior pole widely rounded; posterior pole with very short mammilla; pellicle with levorotatory striations; numerous discoid chloroplasts; two large grains of annular paramylon, lateral and opposite.

Material examined: EAN15475, EAN15476 and EAN15477.

Geographical distribution: Cosmopolitan. Widely distributed within Brazil, having been described in five macroregions of the country.

Lepocinclis oxyuris (Schmarda) Marin \& Melkonian in Marin, Palm, Klingberg \& Melkonian, Protist 154: 104. 2003.

Figures 7 and 35

Cell cylindrical, 157.5-262.5 $\mu \mathrm{m}$ long, 20.0$25.0 \mu \mathrm{m}$ wide; $\mathrm{Rl} / \mathrm{w}=6.3-11.0$; anterior pole rounded or truncated; posterior pole thinner, terminating in a very notable caudal process, 27.5-37.5 $\mu \mathrm{m}$ long; pellicle clearly striated, following the direction of the twisting of the cell; two large paramylon bodies, one anterior and the other posterior to the central nucleus.

Material examined: EAN15469, EAN15470, EAN15471 and EAN15472.

Geographical distribution: Cosmopolitan. Has been reported in the central-western, northern, southeastern, and southern regions of Brazil (as Euglena oxyuris Schmarda var. oxyuris).
Lepocinclis salina Fritsch var. salina, New Phytologist, 13: 351, fig. 3a-b, e. 1914.

Figures 8 and 36

Cell ovate to elliptical, 37.5-55.0 $\mu \mathrm{m}$ long, 27.5$45.0 \mu \mathrm{m}$ wide; $\mathrm{Rl} / \mathrm{w}=1.22-1.36$; transversal optical cut circular; anterior orifice eccentric, prolonged in a lateral depression; posterior pole widely rounded; spiral striations dextrorotary; numerous paramylon grains.

Material examined: EAN15468, EAN15469, EAN15470, EAN15471, EAN15472, EAN15473, EAN15474, EAN15475, EAN15476, and EAN15477.

Geographical distribution: Cosmopolitan. Reported from the central-western, northern, southeastern, and southern regions of Brazil.

Lepocinclis salina Fritsch var. vallicauda Conrad, Mem. Mus. Hist. nat. Belg., 2(10):63. 1942.

Figures 9 and 37

Cell elliptical, $67.5 \mu \mathrm{m}$ long, $40.0 \mu \mathrm{m}$ wide; R1/ $\mathrm{w}=1.7$; anterior pole rounded and eccentric; posterior pole terminating abruptly in a conical, slightly curved caudal process, ca. $10 \mu \mathrm{m}$ long; pellicle colorless or weakly colored with dextrorotary spirals; numerous discoid chloroplasts.

Material examined: EAN15474.

Geographical distribution: Africa and South America. Has been reported from the central-western, northern, southeastern, and southern regions of Brazil.

Commentary: This variety differs from the typical variety by the presence of a developed (ca. $10 \mu \mathrm{m}$ ) and slightly curved caudal process.

Lepocinclis spirogyroides Marin \& Melkonian in Marin, Palm, Klingberg \& Melkonian, Protist 154: 104. 2003.

Figure 10

Cell fusiform, 157.5-180.0 $\mu \mathrm{m}$ long, 22.5-27.5 $\mu \mathrm{m}$ wide; $\mathrm{Rl} / \mathrm{w}=5.7-7.2$; anterior pole rounded; posterior pole conical, terminating in a well-defined, sharp and slightly curved caudal process, 17.5-25.0 $\mu \mathrm{m}$ long; pellicle reddish-brown, spirally striped, with lines of alternately placed polygonal warts; two large bastoniform paramylon bodies, perforated or not.

Material examined: EAN15471 and EAN15476.

Geographical distribution: Cosmopolitan. Reported from the central-western, northern, southeastern, and southern regions of Brazil (as Euglena spirogyra Ehrenberg var. fusca Klebs). 
Phacus Dujardin 1841.

Phacus longicauda (Ehrenberg) Dujardin var. longicauda, Hist. nat. Zoophytes, p. 337, pl. 5, fig. 6. 1841.

Figure 11

Cell obovate, $87.5 \mu \mathrm{m}$ long, $42.5 \mu \mathrm{m}$ wide; R1/ $\mathrm{W}=2.0$; anterior pole rounded; posterior pole attenuated or less abruptly terminated in a very long and thin caudal process, $32.5 \mu \mathrm{m}$ long; pellicle with longitudinal striations; numerous discoid chloroplasts.

Material examined: EAN15471.

Geographical distribution: Cosmopolitan. Has been reported from the northern, southeastern, and southern regions of Brazil.
Phacus longicauda (Ehrenberg) Dujardin var. insecta Koczwara, Kosmos, v. 40, p. 246. 1915.

Figures 12 and 38

Cell elliptical to slightly ovate, $92.5 \mu \mathrm{m}$ long, $30.0 \mu \mathrm{m}$ wide; $\mathrm{R} 1 / \mathrm{w}=3.1$; caudal process $37.5 \mu \mathrm{m}$ long; pellicle with longitudinal strips and lateral recesses; numerous discoid chloroplasts.

Material examined: EAN15475.

Geographical distribution: North America, South America, Asia, and Europe. Has been reported from the northern and southern regions of Brazil.

Commentary: This variety differs from the typical variety by the presence of lateral recesses.
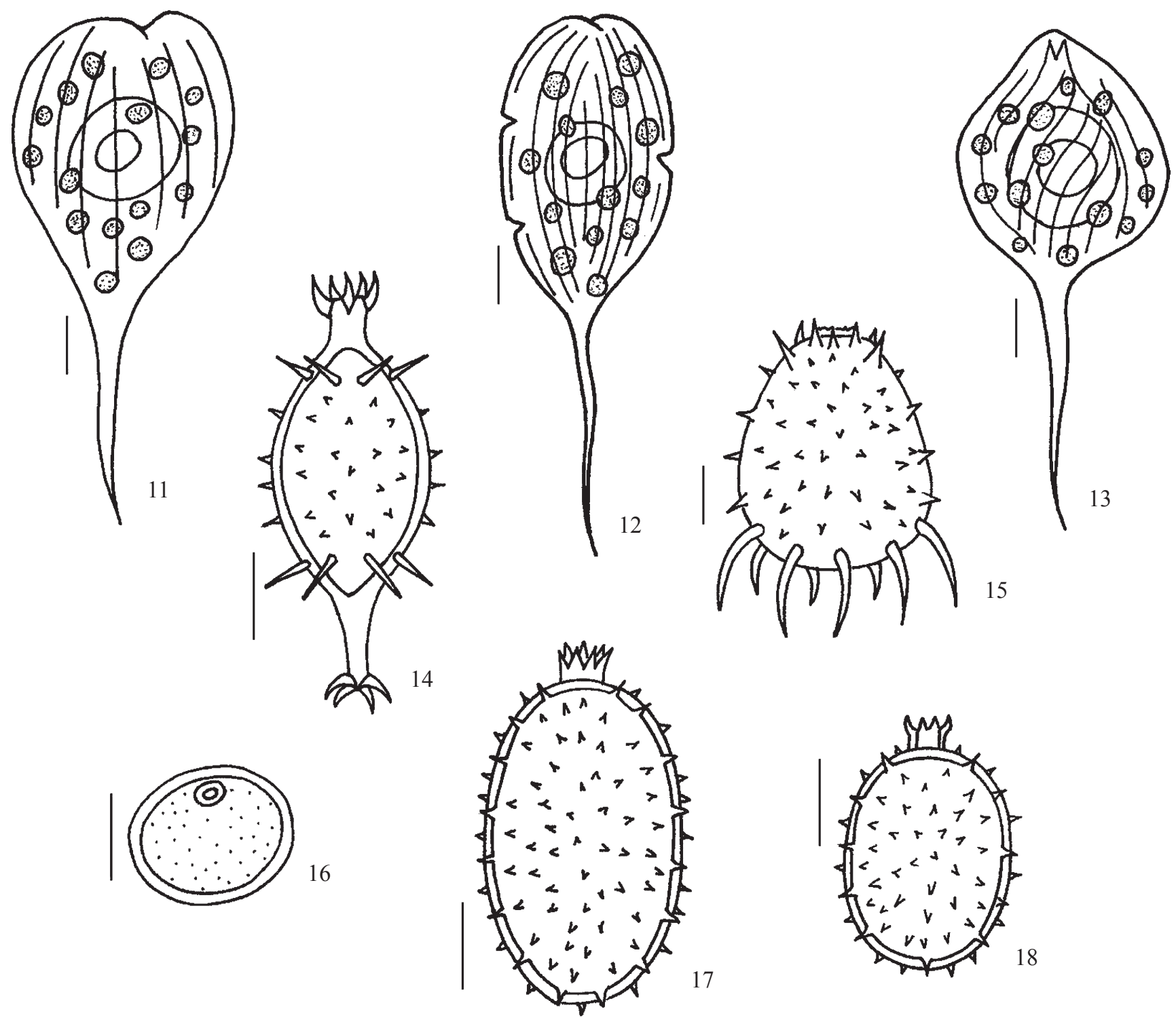

Figures 11-18. 11. Phacus longicauda var. longicauda. 12. Phacus longicauda var. insecta. 13. Phacus longicauda var. tortus. 14. Trachelomonas acanthophora. 15. Trachelomonas armata var. longispina. 16. Trachelomonas curta var. curta. 17. Trachelomonas hispida var. coronata. 18. Trachelomonas hispida var. crenulatocollis. Bar $=10 \mu \mathrm{m}$. 
Phacus longicauda (Ehrenberg) Dujardin var. tortus Lemmermann, Kryptogamenfl. Mark Brandenburg, v. 3, p. 511. 1910.

Figures 13 and 39

Cell ovate twisted, 70.0-72.5 $\mu \mathrm{m}$ long, 35.0-37.5 $\mu \mathrm{m}$ wide; $\mathrm{R} 1 / \mathrm{w}=1.9-2.6$; anterior pole with sides widely extended or little narrowed; posterior pole terminates in an elongated caudal apex, straight or slightly inclined, 32.5-35.0 $\mu \mathrm{m}$ long; pellicle striated following the direction of cell twisting.

Material examined: EAN15471, EAN15475 and EAN15477.

Geographical distribution: North America, South America, Asia, and Europe. Widely distributed in Brazil, having been reported from all five macroregions of that country.

Commentary: Is cited by numerous authors as $P$. tortus (Lemmermann) Skvortzov.

Trachelomonas Ehrenberg emend. Deflandre 1926.

Trachelomonas acanthophora Stokes, Proc. Amer. Philos. Soc. 33: 340, pl. XXI: fig. 6. 1894.

Figures 14 and 40

Periplast elliptical, 50.0-57.5 $\mu \mathrm{m}$ long, 21.2-25.0 $\mu \mathrm{m}$ wide; $\mathrm{R} 1 / \mathrm{w}=2.2-2.6$; anterior pole with cylindrical collar with 4 to 6 spikes; posterior pole continues to a sub-conical caudal process that terminates in three long, sharp, and divergent spines; the periplast is also ornamented with strong sharp spines.

Material examined: EAN15471.

Geographical distribution: North America and South America. Has been reported from the centralwestern, northern, southern, and southeastern regions of Brazil.

Trachelomonas armata (Ehrenberg) Stein var. longispina Playfair emend. Deflandre, Nemours, v. 88, pl. 6, fig. 330. 1926.

Figures 15 and 41

Periplast widely ovate, 57.5-67.5 $\mu \mathrm{m}$ long, 32.5$35.0 \mu \mathrm{m}$ wide; $\mathrm{R} 1 / \mathrm{w}=1.3-1.6$; both poles rounded; wall with conical spines throughout, being small and straight at anterior pole, long and convergent at posterior pole, 17.5-22.5 $\mu \mathrm{m}$ long

Material examined: EAN15471, EAN15472, and EAN15476.

Geographical distribution: Cosmopolitan. Reported from the central-western, northern, and southern regions of Brazil.
Trachelomonas curta Cunha emend. Deflandre var. curta, Bull. Soc. Bot., v. 44, p. 286. 1927.

Figure 16

Periplast sub-globose, $17.5 \mu \mathrm{m}$ long, $20.0 \mu \mathrm{m}$ wide; $\mathrm{Rl} / \mathrm{w}=0.9$; anterior pole with small pore surrounded by notably thick annular ring; wall smooth or finally punctuate.

Material examined: EAN15471.

Geographical distribution: Cosmopolitan. Reported from the central-western, southeastern, and southern regions of Brazil.

Trachelomonas hispida (Perty) Stein emend. Deflandre var. coronata Lemmermann, in Pascher, Süsswasserfl. Deutschl. 2: 150. 1913.

Figures 17 and 42

Periplast widely elliptical, $40.0 \mu \mathrm{m}$ long, 22.5$24.0 \mu \mathrm{m}$ wide; $\mathrm{Rl} / \mathrm{w}=1.7-1.8$; wall covered with small, conical, pointed and irregularly distributed spines; pore with collar ornamented with a crown of strong spines.

Material examined: EAN15471.

Geographical distribution: Cosmopolitan. Has been cited for the central-western, northern, southeastern, and southern regions of Brazil.

Trachelomonas hispida (Perty) Stein emend. Deflandre var. crenulatocollis (Maskell) Lemmermann, Kryptogamenfl. Bradenburg, v. 3, p. 526, 1910.

Figures 18 and 43

Periplast elliptical, 27.5-30.0 $\mu \mathrm{m}$ long, $20.0 \mu \mathrm{m}$ wide; $\mathrm{Rl} / \mathrm{w}=1.4-1.5$; shape and distribution of the spines similar to the other varieties of this species.

Material examined: EAN15471, EAN15472 and EAN15475.

Geographical distribution: Cosmopolitan. Has been cited for the central-western, northern, southeastern, and southern regions of Brazil.

Commentary: Differs from the other varieties by having a prominent collar approximately $5.0 \mu \mathrm{m}$ long.

Trachelomonas magdaleniana Deflandre, Rev. Gen. Bot. 39: 44 (38: pl. 25, figs. 633-634 1926). 1927. (F). 39:81. (L)

Figures 19 and 44

Periplast fusiform, 62.5-77.5 $\mu \mathrm{m}$ long, 15.0-17.5 $\mu \mathrm{m}$ wide; $\mathrm{Rl} / \mathrm{w}=4.2-5.2$; anterior pole with straight collar with four or five thick spines; posterior pole continues as a conical caudal process, 17.5-22.5 $\mu \mathrm{m}$ long, ornamented 
with spines distributed over its entire surface, with three long, sharp spines that converge at their distal extremities; periplast wall light brownish-yellow, ornamented with conical and pointed spines.
Material examined: EAN15471.

Geographical distribution: North and South America. Has been reported for the central-western, northern, and southern regions of Brazil.
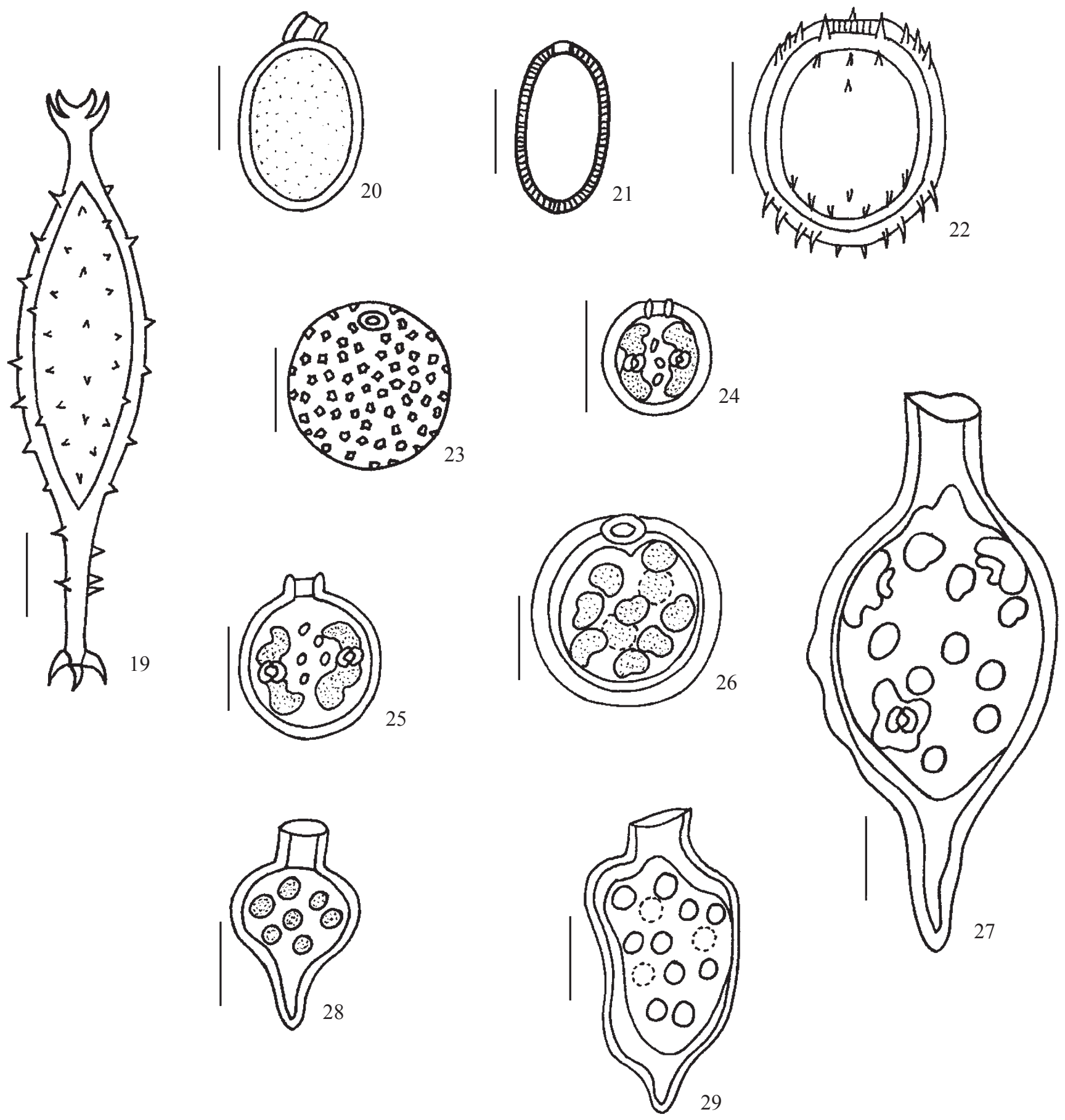

27

Figures 19-29. 19. Trachelomonas magdaleniana. 20. Trachelomonas planctonica var. flexicollis. 21. Trachelomonas pulcherrima. 22. Trachelomonas raciborskii var. raciborskii. 23. Trachelomonas sculpta. 24. Trachelomonas volvocina var. volvocina. 25. Trachelomonas volvocina var. derephora. 26. Trachelomonas volvocinopsis. 27. Strombomonas fluviatilis var. levis. 28. Strombomonas rotunda. 29. Strombomonas triquetra var. torta. Bar $=10 \mu \mathrm{m}$. 
Trachelomonas planctonica Svirenko var. flexicollis Balech, An. Mus. Argent. Cienc. Nat., 41: 279, fig. 103, 211. 1944.

Figures 20 and 45

Periplast elliptical-quadrangular, $25.0 \mu \mathrm{m}$ long, 15.0-16.0 $\mu \mathrm{m}$ wide; $\mathrm{R} 1 / \mathrm{w}=1.6-1.7$; anterior pole with a cylindrical curved collar with an irregularly toothed opening, ca. $4.0 \mu \mathrm{m}$ long; wall thick, punctuate, yellowbrown to dark-red.

Material examined: EAN15476 and EAN15477.

Geographical distribution: Africa, South America, and Europe. Has been reported from the northern, southeastern, and southern regions of Brazil.

Commentary: This variety differs from the typical variety by the presence of a curved collar.

Trachelomonas pulcherrima Playfair, Proc. Linn. Soc. N.S.N. 40:13, pl, I figs. 32, 33. 1915

Figures 21 and 46

Periplast widely elliptical, $20.0 \mu \mathrm{m}$ long, $10.0 \mu \mathrm{m}$ wide; $\mathrm{R} 1 / \mathrm{w}=2.0$; poles rounded; pore surrounded by annular thickenings; wall finely punctate.

Material examined: EAN15475.

Geographical distribution: Cosmopolitan. Has been described from the central-western, northern, southeastern, and southern regions of Brazil.

Trachelomonas raciborskii Woloszýnska var. raciborskii, Bull. Int. Acad. Cracovie, p. 696, fig. 19f, 1912.

Figures 22 and 47

Periplast elliptical, 35.0-37.5 $\mu \mathrm{m}$ long, 30.0$32.5 \mu \mathrm{m}$ wide; $\mathrm{Rl} / \mathrm{w}=1.1-1.6$; strong, conical spines present only near the anterior and posterior extremities; pore $6.0-7.5 \mu \mathrm{m}$, without collar, surrounded by spines; wall dark-brown, thick and punctate.

Material examined: EAN15471, EAN15472, EAN15473, EAN15475, and EAN15476.

Geographical distribution: North and South America and Asia. Has been reported from the central-western, southeastern, and southern regions of Brazil.

Trachelomonas sculpta Balech, An. Mus. Argent. Cienc. Nat., v. 41, p. 245, fig. 32, 167, 1944.

Figure 23

Periplast spherical, ca. $20.0 \mu \mathrm{m}$ diam.; pore surrounded by a thick annular ring; walls thick, orangish to dark brown, with polygonal and isodiametric depressions irregularly distributed over its surface.
Material examined: EAN15472.

Geographical distribution: North America, South America, and Europe. Has been reported for the centralwestern, northern, southeastern, and southern regions of Brazil.

Trachelomonas volvocina Ehrenberg var. volvocina, Infus., v. 48, pl. 2, fig. 29, 1838.

Figure 24

Periplast spherical, 10.0-12.5 $\mu \mathrm{m}$ diam.; annular thickening small, and collar absent or short; wall smooth and reddish; two lateral chloroplasts with double pyrenoids.

Material examined: EAN15470, EAN15471, EAN15472, EAN15473, EAN15474, EAN15475, EAN15476, and EAN15477.

Geographical distribution: Cosmopolitan. Widely distributed in Brazil, with descriptions from all five macroregions of that country.

Trachelomonas volvocina Ehrenberg var. derephora Conrad, Ann. Biol. Lacustre 8: 201, pl. I: fig. 3. 1916. Figures 25 and 48

Periplast spherical, 17.5-20.0 $\mu \mathrm{m}$ diam.; collar subcylindrical, ca. $1.7 \mu \mathrm{m}$; wall thin and reddish.

Material examined: EAN15473, EAN15474, and EAN15477.

Geographical distribution: Africa, North America, South America, and Europe. Has been reported from the central-western, northern, southeastern, and southern regions of Brazil.

Commentary: Differs from the typical variety by the presence of a notable collar, and by its large periplast.

Trachelomonas volvocinopsis Svirenko Arch. Hydrobiol. 9: 33, pl. 19: figs. 1,2. 1914.

Figures 26 and 49

Periplast spherical, 22.5-25.0 $\mu \mathrm{m}$ diam.; pore small, annular thickening present and collar absent; wall smooth, reddish-brown; numerous discoid chloroplasts without pyrenoids.

Material examined: EAN15468, EAN15469, EAN15470, EAN15471, EAN15472, EAN15474, and EAN15475.

Geographical distribution: Cosmopolitan. Is widely distributed in Brazil, having been registered in all five macroregions of that country. 
Strombomonas Deflandre 1930.

Strombomonas fluviatilis (Lemmermann) Deflandre var. levis (Lemmermann) Skvortzov., Aus der Biol. Sungari Station zur Harbin 1(2): 78, pl. 6, fig. 33. 1925.

Figure 27

Periplast elliptical, yellowish, 65.0-70.0 $\mu \mathrm{m}$ long, $30.0 \mu \mathrm{m}$ wide; $\mathrm{R} 1 / \mathrm{w}=2.2-2.3$; anterior pole terminating in a collar, ca. $11.2 \times 7.5 \mu \mathrm{m}$; posterior pole abruptly attenuating in a conical, straight caudal process, ca. $15.0 \mu \mathrm{m}$ long; numerous discord chloroplasts, ca. $4.4 \mu \mathrm{m}$.

Material examined: EAN15477.
Geographical distribution: Cosmopolitan. Has only been reported from southern Brazil.

Strombomonas rotunda (Playfair) Deflandre, Arch. Protistenk. 69(3): 593, fig. 88, 1930.

Figure 28

Periplast with median region transversely elliptical, ca. $25.0 \mu \mathrm{m}$ long, $15.0-17.5 \mu \mathrm{m}$ wide; $\mathrm{R} 1 / \mathrm{w}=1.4-1.7$; anterior pole attenuating abruptly at a thick, long collar, $5.0 \mu \mathrm{m}$ long and $7.5 \mu \mathrm{m}$ wide; posterior pole abruptly attenuating into a strong, straight, and conical caudal process, $7.5 \mu \mathrm{m}$ long.
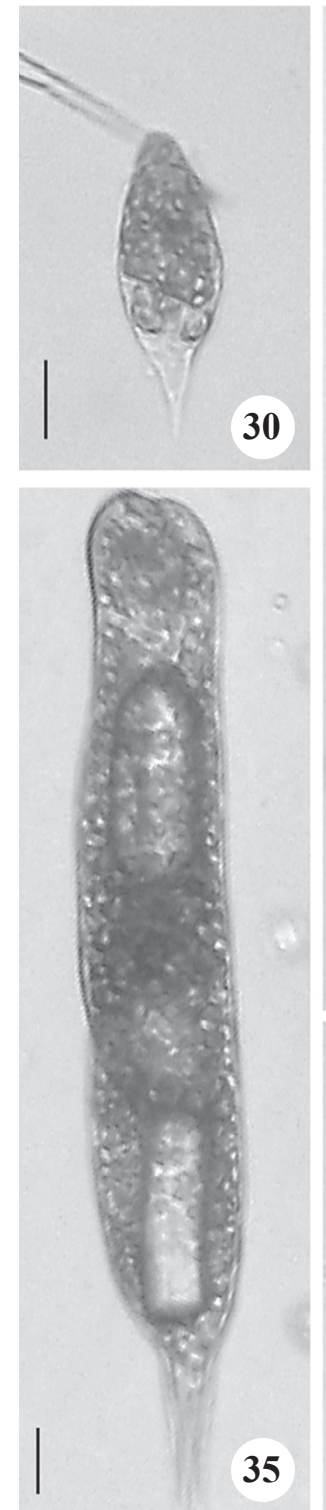
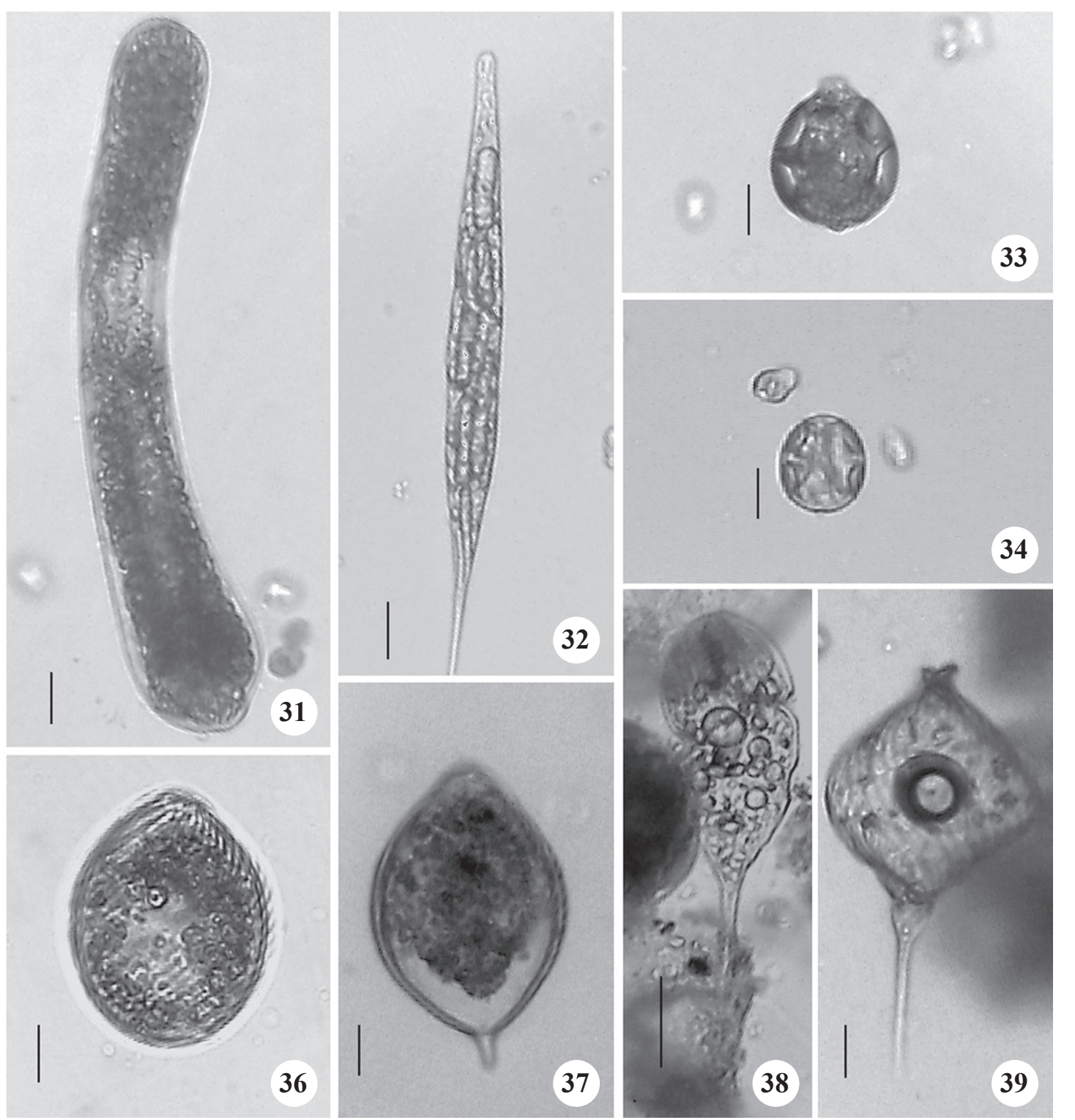

34

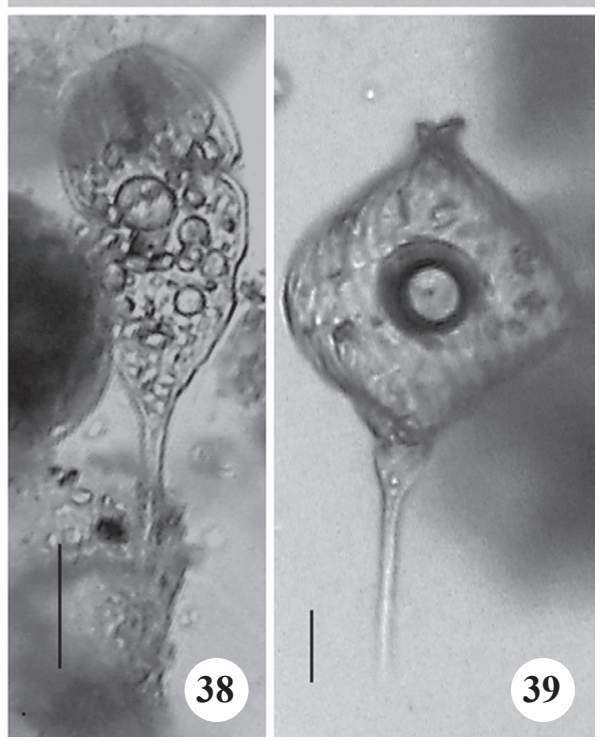

Figures 30-39. 30. Euglena caudata. 31. Euglena ehrenbergii var. baculifera. 32. Lepocinclis acus. 33. Lepocinclis fusiformis var. amphirhynchus. 34. Lepocinclis ovum var. globula. 35. Lepocinclis oxyuris. 36. Lepocinclis salina var. salina. 37. Lepocinclis salina var. vallicauda. 38. Phacus longicauda var. insecta. 39. Phacus longicauda var. tortus. Bar $=10 \mu \mathrm{m}$. 
Material examined: EAN15470, EAN15476 and EAN15477.

Geographical distribution: North America, South America, Asia, Australia, and Oceania. Has been reported from the northern, southeastern, and southern regions of Brazil.

Commentary: Has a total length slightly inferior to that reported by Alves-da-Silva \& Bridi (2004b); however, within the size limits indicated by Tell \& Conforti (1986).
Strombomonas triquetra (Playfair) Deflandre var. torta Rino, Rev. Ciênc. Biol., Fac. Ci. Lourenço Marques, A, 5: 169, pl. 9, fig. 7-10. 1972.

Figures 29 and 50

Periplast slightly triangular to trapezoidal, 32.5$42.5 \mu \mathrm{m}$ long, 20.0-22.5 $\mu \mathrm{m}$ wide; $\mathrm{Rl} / \mathrm{w}=1.6-1.9$; anterior pole abruptly attenuated in a wide, oblique, truncated collar, ca. $5.0 \times 7.5 \mu \mathrm{m}$; posterior pole converges to a short, sharp caudal apex; wall rugose or granular, light-brown to medium-brown; numerous discoid chloroplasts.
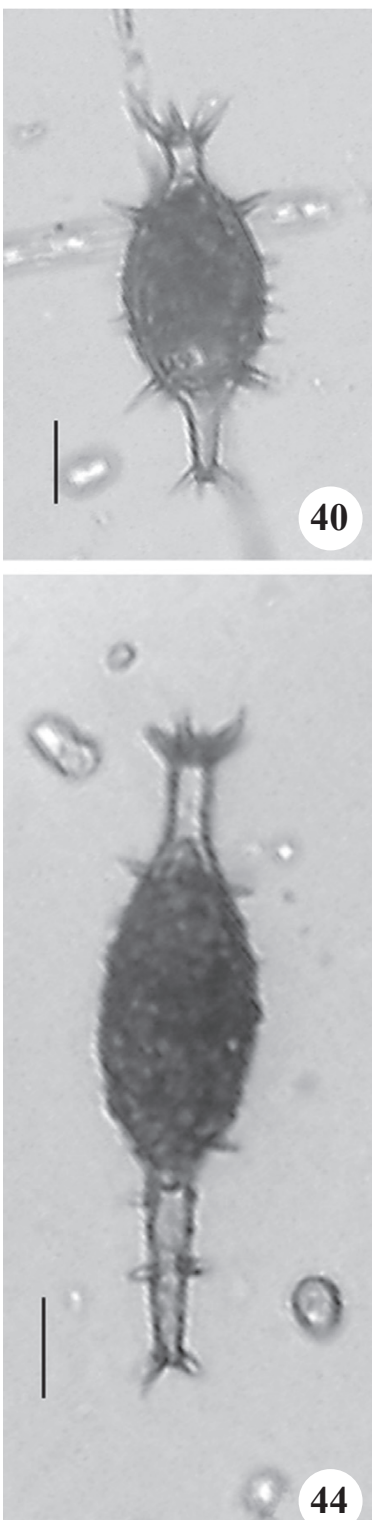
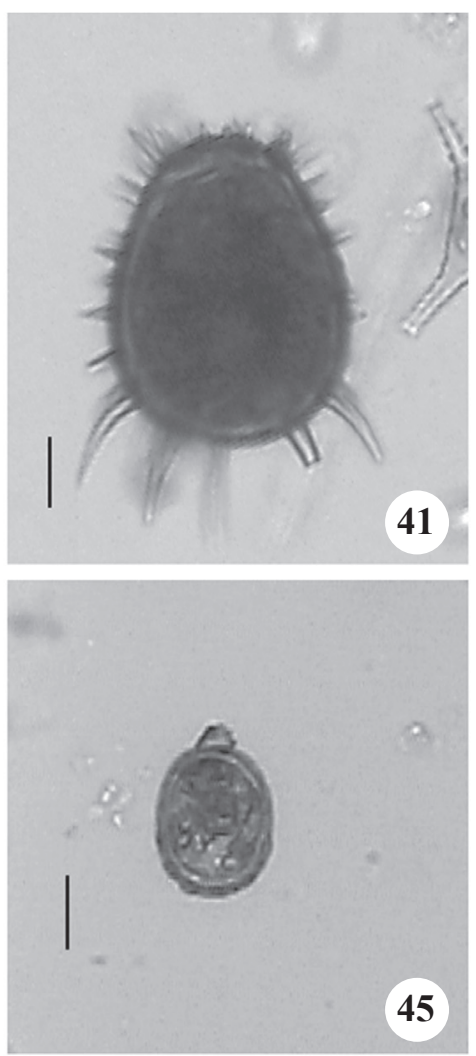

45

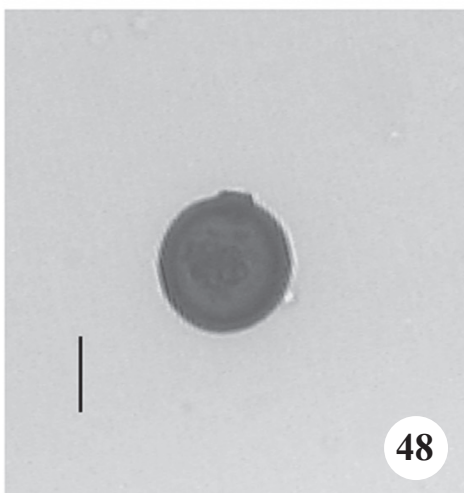

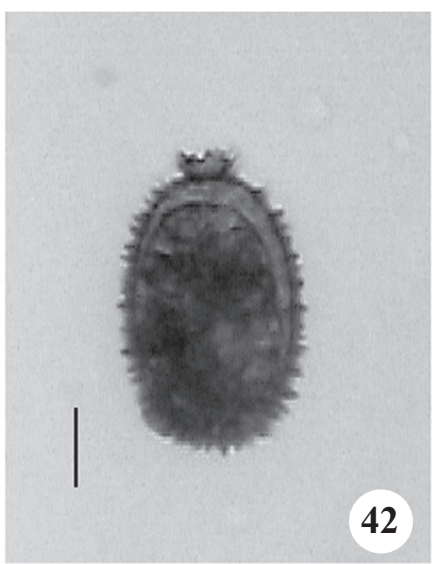
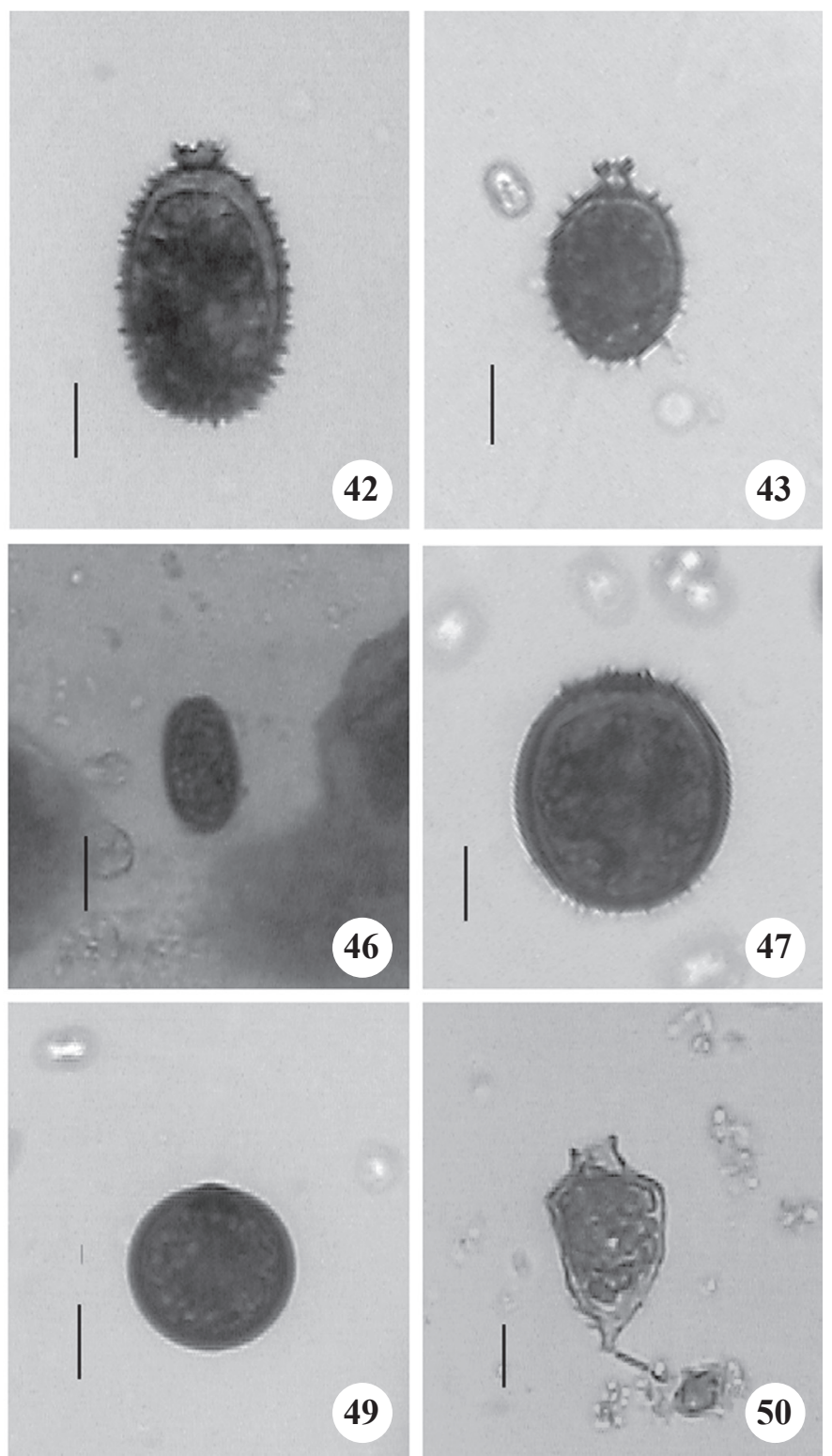

Figures 40-50. 40. Trachelomonas acanthophora. 41. Trachelomonas armata var. longispina. 42. Trachelomonas hispida var. coronata. 43. Trachelomonas hispida var. crenulatocollis. 44. Trachelomonas magdaleniana. 45. Trachelomonas planctonica var. flexicollis. 46. Trachelomonas pulcherrima. 47. Trachelomonas raciborskii var. raciborskii. 48. Trachelomonas volvocina var. derephora. 49. Trachelomonas volvocinopsis. 50. Strombomonas triquetra var. torta. Bar $=10 \mu \mathrm{m}$. 
Material examined: EAN15470 and EAN15476.

Geographical distribution: Africa, South America, and Asia. Has only been reported from southern Brazil.

\section{DISCUSSION}

The class Euglenophyceae is an important group in terms of its richness and abundance in shallow aquatic ecosystems with high concentrations of organic materials (Tell \& Conforti 1986). Panati is a shallow, temporary lake with a high abundance of aquatic macrophytes (Crispim \& Freitas 2005). Reynolds et al. (2002) indicated shallow, meso-eutrophic lakes that are rich in organic materials as ideal habitats for the growth of Euglenophytes, and these organisms are components of the functional groups $\mathrm{W}_{1}$ and $\mathrm{W}_{2}$.

Euglenophyta are known to occur in environments rich in organic material (Buetow 1968, Palmer 1980, Round 1983, Rosowski 2003) as the Euglenaceae demonstrate high degrees of heterotrophy (Esteves 1998). Analyses of the bottom sediments of Panati Lake indicated high concentrations of organic material throughout the year (Souza \& Abílio 2006). Two origins are proposed for the organic material encountered in that lake: i) of autochthone origin (sediments) during most of the year due to high turbidity levels and the shallow depth of the water column; ii) of aloctone origin during the months of the highest rainfall. It should be noted that there is also a permanent contribution from the decomposition of aquatic macrophytes - a continuous process in topical aquatic freshwater ecosystems as climatic conditions are favorable to their growth during the entire year (Esteves 1998).

We observed significant increases in the numbers of taxa during the rainy seasons of 2006 and 2007 related to the arrival of species from the periphyton and the entrance of aloctone organic material - specifically, 16 taxa $(55.2 \%)$ exclusive to the rainy season but only three taxa $(10.3 \%)$ exclusive to the dry period (Lepocinclis salina Fritsch var. vallicauda Conrad, Phacus longicauda var. insecta, and Trachelomonas pulcherrima).

The genus Trachelomonas demonstrated the greatest riches (13 taxa), followed by the genus Lepocinclis (7 taxa). Alves-da-Silva \& Hahn (2001) noted that there was a consistently high probability of the genera Trachelomonas and Phacus having large larger numbers of taxa in these types of aquatic surveys. In the present work, however, we identified only a single species and three varieties of the latter genus (Phacus longicauda var. longicauda, $P$. longicauda var. insecta, and P. longicauda var. tortus).

Lepocinclis salina var. salina had the greatest occurrence, being observed in all of the samples analyzed. Alves-da-Silva \& Fortuna (2006) likewise reported this species as the most frequent in lake environments on the coastal plains of Rio Grande do Sul State, Brazil. The taxa Lepocinclis fusiformis var. amphirhynchus, Lepocinclis salina var. vallicauda, Phacus longicauda var. longicauda, P. longicauda var. insecta, Trachelomonas acanthophora, T. curta var. curta, T. hispida var. coronata, T. magdaleniana, $T$. pulcherrima, T. sculpta, and Strombomonas fluviatilis var. levis were considered rare as they each appeared in only a single sample.

The most frequent specific and infraspecific taxa were Trachelomonas volvocina var. volvocina $(80 \%$ of the samples), T. volvocinopsis (70\%), T. raciborskii var. raciborskii (50\%), Lepocinclis acus (40\%), and $L$. oxyuris $(40 \%)$ - all of which showed wide tolerance to the alternating levels of rainfall and a number of other environmental parameters, principally electrical conductivity and the concentrations of nitrogen compounds. With the exception of Trachelomonas raciborskii var. raciborskii, all of the taxa cited here were cosmopolitan and commonly encountered in Brazil and had been previously reported in at least four macroregions.

In relation to their global geographical distributions, among the 29 taxa identified, 14 are cosmopolitan $(48.3 \%), 11$ are known to be distributed on three or more continents $(37.9 \%)$, while only four $(13.8 \%)$ were cited for only two localities: Euglena ehrenbergii var. baculifera, Trachelomonas acanthophora, and T. magdaleniana are known only from North and South America; while Lepocinclis salina var. vallicauda is known only from Africa and South America.

All of the taxa had been previously recorded in Brazil, and the majority had wide distributions there, with 24 taxa (82.8\%) having previously been found in at least three geographical regions in the country. The taxon Euglena ehrenbergii var. baculifera, cited for the northern region, and the taxa Strombomonas fluviatilis var. levis and S. triquetra var. torta, cited for the southern region, had the most limited distributions within Brazil. Lepocinclis fusiformis var. amphirhynchus and Phacus longicauda var. insecta also had limited distributions, having been reported only from southern and northern Brazil.

The present study constitutes the first citation for all of these taxa in Paraíba State, and the first citation for 
northeastern Brazil for 25 of them. The only taxa that had been previously recorded for northeastern Brazil were: Lepocinclis ovum var. globula, Phacus longicauda var. tortus, Trachelomonas volvocina var. volvocina, and $T$. volvocinopsis, which had been previously reported only from Pernambuco State; Trachelomonas volvocinopsis had also been identified from Rio Grande do Norte State. These results reflect the low numbers of studies concerning euglenophytes in northeastern Brazil, especially in Paraíba state.

Acknowledgments - The authors would like to thank Deutscher Akademischer Austauschdienst (DAAD) for the Masters grant, and the Programa de Pesquisas Ecológicas de Longa Duração com sítio na Caatinga (PELD-Caatinga/ $\mathrm{CNPq}$ ) for financial support for this project.

\section{REFERÊNCIAS}

Alves-da-Silva SM, Bicudo CEM. 2009. Cryptoglena, Monomorphina and Phacus (Euglenophyceae) of a reservoir in the State of Rio Grande do Sul, southern Brazil. Revista Brasileira de Botânica 32: 253-270.

Alves-da-Silva SM, Bridi FC. 2004a. Estudo de Euglenophyta no Parque Estadual Delta do Jacuí, Rio Grande do Sul, Brasil. 2. Os gêneros Phacus Dujardin e Hyalophacus (Pringshein) Pochmann. Iheringia 59: 75-96.

Alves-da-Silva SM, Bridi FC. 2004b. Euglenophyta no parque Estadual Delta do Jacuí, Rio Grande do Sul, Sul do Brasil. 3. Gênero Strombomonas Defl. Acta Botanica Brasilica 18:555-572.

Alves-da-Silva SM, Fortuna JR. 2006. Euglenophyceae de ambientes lênticos na planície costeira do Rio Grande do Sul, sul do Brasil: gêneros Euglena Ehr. e Lepocinclis Perty. Acta Botanica Brasilica 20:411-422.

Alves-da-Silva SM, Fortuna JR. 2008. O gênero Phacus (Euglenophyceae) em sistemas lênticos da Planície Costeira do Rio Grande do Sul, sul do Brasil. Acta Botanica Brasilica 22:684-700.

Alves-da-Silva SM, Hahn AT. 2001. Lista de Euglenophyta registradas em ambientes de águas continentais e costeiras do Estado do Rio Grande do Sul, Brasil. Iheringia 55:171-188.

Alves-da-Silva SM, Hahn AT. 2004. Study of Euglenophyta in the Jucuí Delta State Park, Rio Grande do Sul, Brazil. 1. Euglena Ehr., Lepocinclis Perty. Acta Botanica Brasilica 18:123-140.

Alves-da-Silva SM, Tamanaha MS. 2008. Ocorrência de Euglenophyceae pigmentadas em rizipiscicultura na Região do Vale do Itajaí, SC, Sul do Brasil. Acta Botanica Brasilica 22:145-163.
Brosnan S, Shin W, Kjer LM, Trimer RE. 2003. Phylogeny of the photosynthetic Euglenophytes inferred from the nuclear SSU and partial LSU rDNA. International Journal of Systematic and Evolutionary Microbiology 53:1175-1186.

Buetow DE. 1968. The biology of Euglena, v.1. General biology and ultrastructure. Academic Press, New York.

Conforti VTD. 1994. Study of the Euglenophyta from Camaleão Lake (Manaus, Brazil). III. Euglena Ehr., Lepocinclis Perty, Phacus Duj. Revue Hidrobiologique Tropicale 27:3-21.

Crispim MC, Freitas GTP. 2005. Seasonal effects on zooplanktonic community in a temporary lagoon of northeast Brazil. Acta Limnologica Brasiliensia 17: 385-393.

Esteves FA. 1998. Fundamentos de Limnologia. Interciência/ Finep, Rio de Janeiro.

Freire-de-Góis SA. 1978. Algumas espécies de Trachelomonas Ehr. (Euglenophyceae) e suas implicações para o tratamento da água. Revista Nordestina de Biologia 1:21-29.

Giani A, Figueredo CC, Eterovick PC. 1999. Algas planctônicas do reservatório da Pampulha (MG): Euglenophyta, Chrysophyta, Pyrrophyta, Cyanobacteria. Revista Brasileira de Botânica 22:107-116.

Gibbs S. 1978. The chloroplasts of Euglena may have evolved from symbiotic green algae. Canadian Journal of Botany 56:2883-2889.

Golterman HL, Clymo RS, Ohnstad MAM. 1978. Methods for physical \& chemical analysis of fresh waters. 2 ed. Blackwell Scientific Publications, Oxford and Edinburg.

Mackereth FJH, Heron J, Talling FJ. 1978. Water analysis: some revised methods for limnologists. Titus Wilson \& Sons Ltd, Kendall.

Marin B, Palm A, Klingber M, Melkonian M. 2003. Phylogeny and taxonomic revision of plastid-containing Euglenophytes based on SSU rDNA sequence comparisons and synapomorphic signatures in the SSU rRNA secondary structure. Protist 154:99-145.

PalmerCM. 1980. Algae and water pollution: the identification, significance and control algae in water supplies and in polluted water. Castle House Publication, London.

Rai SK, Rai RK. 2007. Some euglenophycean algae from Biratnagar, Nepal. Our Nature 5:60-66.

Reynolds CS, Huszar V, Kruk C, Naselli-Flores L, Melo S. 2002. Towards a functional classification of the freshwater phytoplankton. Journal of Plankton Research 24:417-428.

Rodier J. 1975. L'analyse de l'eau: eaux naturelles, euax résiduales, eaux de mer. 5 ed, Dunod, Paris.

Rosowski JR. 2003. Photosynthetic Euglenoids. In Freshwater algae of North America: ecology and classification (JD Wehr, RG Sheath, eds.). Academic Press, New York. p.383-422.

Round F. 1983. Biologia das algas. 2 ed., Ed. Guanabara Dois, Rio de Janeiro. 
Salazar C 2004. Euglenophyta pigmentadas asociadas a Hymenachne amplexicaulis en una sabana tropical inundable. Acta Botanica Venezuelica 27:101-125.

Souza AHFF, Abílio FJP. 2006. Zoobentos de duas lagoas intermitentes da caatinga paraibana e as influências do ciclo hidrológico. Revista de Biologia e Ciências da Terra 1:146-164.

Tell G, Conforti V. 1986. Euglenophyta pigmentadas de la Argentina. J. Cramer (Bibliotheca Phycologica 75), Stuttgart.
Yacubson S. 1974. El fitoplancton de la laguna de San Javier del Valle (Estado Mérida), Venezuela. Revue Algologique 11:91-131.

Yacubson S. 1981. The phytoplankton of some freshwater bodies from Zulia State (Venezuela). Nova Hedwigia 33:279-339.

Zaburlín NM, Goñi O, Conforti V. 2004. Estúdio taxonômico de las Strombomonas (Euglenophyta) del arroyo Yacarey, provincia de Corrientes, Argentina. Iheringia 59:117-130. 